\title{
Büttner, Nils.
}

\section{Hieronymus Bosch: Visions and Nightmares.}

London: Reaktion Books, 2016. Pp. 208 + 63 colour ill. ISBN 978-1-178023579-0 (hardcover) US\$22.50.

First, let us examine this small and affordable new book in relation to its larger series. Reaktion Books of London is issuing titles under the heading Renaissance Lives, which will offer at least a cluster of titles about major artists as well as "intellectuals and scientists in the early modern world." Two titles have already appeared on the publisher's website: Troy Thomas on Caravaggio and Tom Nichols on Tintoretto. I am aware of other volumes in progress: Bernadine Barnes on Michelangelo, Maria Loh on Titian, and (full disclosure) my own book on Rembrandt in Holland. The series is clearly geared to a general readership and includes serviceable colour images to accompany its text by appropriate scholars.

Nils Büttner usually publishes in German, so he might be unfamiliar to non-specialists, but he is Professor of Art History at the State Academy of Art and Design in Stuttgart and has published a number of studies of Bosch and his legacy. A specialist in northern painting of the early modern period, he is also the author of important survey biographies of Vermeer (2010) and Rubens (2007) in the same format, a similar series by C. H. Beck. Indeed, this book is a translation by Anthony Mathews of his Bosch biography, published (2012) by Beck.

In many respects, this well-researched sketch is most welcome, especially for classroom teaching. Its principal rival, the fine analysis by Walter Gibson (Thames and Hudson), dates back to 1977, and though it still holds up well, it has gone out of print recently. But there is one disappointment in terms of timing: 2016 is a Bosch centennial year, marking five hundred years since his death, and important new information (as well as numerous newer publications) is mushrooming, which has not been incorporated into the Reaktion volume. It would have been far better if Büttner had been allowed a text update, or at least an appendix incorporating newer findings (often technical studies of underdrawings) and recent references, both scholarly and popular, for interested readers. But his research is quite thorough on documents and even on the technical findings, which he incorporates in discussion, and his insights are often original rather than conventional wisdom. 
What does this book give us? Its terse, clear prose provides the bare bones of Bosch biography, insofar as it is known, as well as documented early collecting of these works. Then it delves individually into the two dozen paintings now accepted as authentic. It eschews psychobiography or easy correlations with occult learning, alchemy, or astrology in favour of adherence to historical sources, some fifty in number. Bosch came from a family of painters-three generations-in the small Brabant town of 's-Hertogenbosch, from which he takes his name (the family name, van Aken, indicates origins in Aachen). As a relatively wealthy citizen, he was a member of the noble Brotherhood of Our Lady, for which he painted part of a sculpted retable in the local cathedral and other works. His known patrons included the Duke of Burgundy, Philip the Fair (a lost large Last Judgment Triptych, 1504); his most famous work, The Garden of Delights (Prado), was recorded by 1517 in the Brussels townhouse of Hendrik III of Nassau-Breda. Büttner efficiently lays out these and related facts and considers the few other known commissions, all lost.

When he turns to the images, like Gibson, Büttner puts the religious imagery, particularly the saints, into a late medieval context. He responds to their pictorial qualities as well, noting that his spaces are not observed landscapes as such but settings for events. He also notes that unlike the meticulous details of fifteenth-century Flemish panels, Bosch paints with fluid brushwork and blended colouring. This artist innovates not simply in his imaginative monsters and hell scenes but also in his very technique. Bosch also tars the enemies of Jesus pointedly with pseudo-Oriental references to Turks, which run across many of his images. Büttner's analysis (57f.) of the Antichrist figure in the Prado Adoration of the Magi (fig. 14) is clear and efficient, and it anticipates the important new monograph on the triptych by Debra Higgs Strickland (2016).

Dates provided with the captions are rarely justified (but see 68f.) and only span a narrow range of years, though Bosch chronology has almost no fixed points, and even the major 2016 exhibitions in Den Bosch and Madrid abandoned any effort to justify even a relative development. Büttner follows those exhibitions and most other Bosch studies by organizing his chapters by theme and by focusing on significant works: first saints, then inventive imagery (including drawings) of Creation run amok; the Seven Deadly Sins and Last Judgment; and finally, perhaps most lastingly, the depiction of worldly folly, particularly in the major triptychs, The Haywain and The Garden of Delights. Later copies after Bosch are clearly distinguished in the discussion of the folly 
themes. Finally, a summary of interpretations, chiefly the long legacy of Bosch, especially in Pieter Bruegel's Antwerp, concludes the volume.

In the main, however, Büttner emphasizes the unique vision, not the family workshop, of this distinctive painter. He does not see Bosch as emerging out of Flemish precedents, but instead lays out how his unique imagery could capture the imagination of his contemporaries as well as his numerous (often anonymous) copyists and followers.

LARRY SILVER

University of Pennsylvania

\section{D’Albret, Jeanne.}

Letters from the Queen of Navarre with an Ample Declaration. Ed. and trans. Kathleen M. Llewellyn, Emily E. Thompson, and Colette H. Winn.

The Other Voice in Early Modern Europe: The Toronto Series 43. Toronto: Iter Academic Press / Tempe, AZ: Arizona Center for Medieval and Renaissance Studies, 2016. Pp. xi, 116. ISBN 978-0-8669-8545-1 (paperback) US\$31.95.

In this latest volume from the renowned Other Voice series, Kathleen Llewellyn, Emily Thompson, and Colette Winn turn attention to one of the most powerful political women of sixteenth-century Europe, Jeanne d'Albret, Queen of Navarre. Along with Elizabeth I of England and Catherine de' Medici in France, Jeanne d'Albret played a leading role in the religious and political conflicts that marked the second half of the sixteenth century. In 1560, Jeanne publicly embraced Protestantism and three years later instituted Reformed practices throughout her Pyrenean kingdom of Béarn, transforming the semi-independent principality into a dangerous Protestant bastion poised between two of the most devoutly Catholic kingdoms in Continental Europe. Over the course of the 1560s, Jeanne deployed her vast fortune, mobilized patronage networks, and leveraged her political influence at court to advance the cause of her co-religionaries. In 1568, facing the twin threat of a noble rebellion and a royal invasion of her territories, Jeanne (with her son, the future Henry IV of France, in tow) took refuge in the Huguenot stronghold of La Rochelle. Behind the massive fortifications of the Atlantic port city, she continued to direct the Protestant insurgency, raising funds for the Huguenot army under the military leadership of her brother-in-law, the Prince de Condé. A year later, the Queen of Navarre penned a detailed memoir, entitled Ample Declaration, in which she defended her actions and 